\title{
Konsep Pendidikan Agama Islam Perspektif Imam Al-Ghazali
}

\author{
ARY ANTONY PUTRA \\ Fakultas Agama Islam (FAI) Universitas Islam Riau (UIR) Pekanbaru \\ Jl. Kaharuddin Nasution, No. 113 Perhentian Marpoyan Pekanbaru 28284 \\ Telp : 081319952829 email : aryantonyp@gmail.com
}

\begin{abstract}
Abstrak: Secara umum penelitian ini bertujuan untuk mengetahui konsep pendidikan agama islam menurut Imam Al-Ghazali, Adapun tujuan spesifik penelitian ini adalah Untuk mengetahui pemikiran al-Ghazali tentang ilmu pengetahuan, dan untuk mengetahui pemikiran al-Ghazali tentang konsep pendidikan Islam. Untuk menjawab tujuan penelitian tersebut Dalam penelitian kepustakaan ini digunakan metode teknik analisa data kualitatif yaitu analisa data reflektif thinking, yaitu teknik analisa data dengan proses pemikiran hilir mudik. Selain itu, untuk menganalisa data yang ada, penulis juga menggunakan metode komparatif, yaitu meneliti faktor-faktor dengan situasi atau fenomena yang diselidiki dan membandingkan dari satu faktor dengan faktor lain. Temuan dari penelitian ini memperlihatkan bahwa Ilmu Pengetahuan merupakan sumber untuk memperoleh kebahagiaan di dunia dan akhirat. Dengan ilmu pengetahuan akan menjadikan manusia menjadi makhluk yang mulia dan terhormat dibandingkan makhluk lainnya. Sedangkan pemikiran al-Ghazali tentang konsep pendidikan Islam Pertama, faktor-faktor pendidikan pendidikan islam, yakni (a) tujuan utama dalam menuntut ilmu adalah untuk memperoleh kebahagiaan hidup di dunia dan akhirat, maka yang dijadikan landasan utama dalam bidang pendidikan adalah alQur'an dan Hadis; (b) seorang pendidik harus mempunyai niat awal dalam mendidik untuk mendekatkan diri kepada Allah, menjadi tauladan bagi murid-muridnya serta mempunyai kompetensi dalam mengajar; (c) anak didik dalam belajar harus mempunyai niat untuk mendekatkan diri kepada Allah, menjauhi maksiat karena ilmu itu suci dan tidak akan deberikan kepada hal yang tidak suci, menghormati guru dan rajin belajar dengan mendalami pelajaran yang telah diberikan gurunya; (d) kurikulum sebagai alat pendidikan harus disesuaikan dengan perkembangan anak didik; (e) anak didik harus dijauhkan dari pergaulan yang tidak baik, karena lingkungan yang jelek akan mempengaruhi perkembangan anak didik, terutama dilingkungan keluarga, sekolah atau masyarakat. Kedua, wujud penerapan nilai-nilai pendidikan dalam perspektif al-Ghazali di masa sekarang ditandai dengan munculnya model-model lembaga pendidikan yang mencantumkan nilai-nilai pendidikan Islam dalam kurikulumnya, seperti sholat dhuha, tadarus al-Qur,an dan sholat berjama'ah.
\end{abstract}

Kata Kunci: Ilmu Pengetahuan, Pendidikan, Imam Al-ghazali, Agama Islam.

\section{PENDAHULUAN}

Pendidikan sangat diperlukan lebih-lebih dalam kehidupan manusia saat ini, pada zaman era globalisasi yang ditandai dengan terjadinya perubahan-perubahan yang serba cepat dan kompleks, baik yang menyangkut perubahan nilai maupun struktur yang berkaitan dengan kehidupan manusia. Sehingga dapat dikatakan pendidikan merupakan kebutuhan mutlak yang harus dipenuhi sepanjang hayat, tanpa pendidikan sangat mustahil manusia dapat hidup dan berkembang sejalan dengan perubahan zaman. (Nurdin, 2008: 35). 
Bersamaan dengan perputaran dunia, modernisasi dan pengembangan ilmu pengetahuan dari hari ke hari semakin berkembang, akhir-akhir ini kita melihat banyak generasi Islam yang sudah tidak mengenal para tokoh Islam yang sangat berpengaruh terhadap kemajuan dunia pendidikan. Mereka kadang meremehkan dengan mengatakan, "Di mana tokoh Islam". Hal ini terjadi karena mereka kurang mengenal terhadap beberapa tokoh Islam yang berhasil mencetak generasi yang tidak kalah hebat dengan tokoh pendidikan non-Muslim dalam mencetak generasi berakhlak alkarimah, disiplin, terhormat, serta bermanfaat untuk kepentingan agama, nusa, dan bangsa.

Negara Indonesia memang bukanlah negara yang menganut sitem pemerintahan Islam, dasar-dasar hukum negara tidak sepenuhnya diambil dari al-Qur'an dan Hadis, namun nilai-nilai ajaran Islam sangat kental dan mendarah daging dalam kehidupan masyarakat, hal ini tidak lain karena warga Indonesia mayoritas memeluk agama Islam, sehingga nilainilai pendidikan Islam juga mempengaruhi tujuan dan sistem pendidikannya. Tujuan pendidikan dalam Islam menurut Djumransjah dan Abdul Malik Karim Amrullah mengutip pendapat Imam al-Ghazali adalah pendidikan yang mempuyai tujuan pertama, kesempurnaan manusia yang puncaknya adalah dekat kepada Allah, kedua, kesempurnaan manusia yang puncaknya adalah kebahagiaan dunia dan akhirat (Amrullah, dan Djumransjah. 2007: 73).

Sementara Muhammad Athiyah alAbrasyi (seorang ahli pendidikan Mesir) berpendapat bahwa tujuan pendidikan Islam adalah pembentukan akhlaqul karimah adalah tujuan utama pendidikan Islam. Para ulama dan sarjana muslim dengan penuh perhatian berusaha menanamkan akhlak mulia yang merupakan fadhilah dalam jiwa anak didik, sehingga mereka terbiasa berpegang pada moral yang tinggi dan terhindar dari hal-hal yang tercela dan berpikir secara rohaniah dan jasmaniah (perikemanusiaan), serta menggunakan waktu untuk belajar ilmu duniawi dan ilmu keagamaan tanpa memperhitungkan keuntungan-keuntungan materi. (Amrullah, dan Djumransjah, 2007: 74).

Selanjutnya Abuddin Nata memberikan pengertian, bahwa pendidikan Islam adalah pendidikan manusia seutuhnya, akal dan hatinya, rohani dan jasmaninya, akhlak dan keterampilannya (Nata, 2001: 20).

Tujuan pendidikan dalam Islam sejalan dengan pendidikan nasional, dimana tujuannya adalah membentuk manusia seutuhnya, baik dalam segi jasmani maupun rohani, intelektual maupun spiritual. Dengan kompleksnya tujuan pendidikan terebut, maka yang dibutuhkan anak didik tidak hanya tambahan pengetahuan secara intelektual, tetapi juga nilai-nilai moral yang sangat dibutuhkan dalam kehidupan. Oleh karena itu, kehadiran guru sebagai pendidik, dalam arti selain sebagai pentrasfer pengetahuan juga merupakan suritauladan bagai anakanak didiknya, dan diharapkan suritauladan yang telah dicontohkan itu mampu tercermin dalam perilaku keseharian anak didik di masyarakat.

Melihat realitas pendidikan yang ada, ternyata produk-produk pendidikan kita menghasilkan orangorang yang korup, suka bertengkar dan mata duitan. Dengan melihat betapa besarnya peran pendidikan Islam dalam membentuk kepribadian anak didik, maka penulis ingin mengkaji pendidikan Islam terutama pendidikan Islam dalam perspektif al-Ghazali. 
Imam al-Ghazali selain sebagai ulama yang ahli dalam bidang agama, pandangan beliau tentang pendidikan dapat dibilang sangat lengkap, tidak hanya menitik beratkan pada nilai-nilai agama Islam, tetapi juga profesional dalam hal keilmuan. Pendapat alGhazali tentang pendidikan tidak menuntut peran anak didik untuk patuh terhadap guru pada kondisi apapun, tetapi wajib mematuhi selama tidak bertentangan dengan perintah Allah. Di sisi lain, al-Ghazali juga menuntut guru untuk profesional dan selalu menjaga diri dari hal-hal yang dilarang Allah, karena guru menjadi teladan bagi murid-muridnya

Al-Ghazali merupakan salah satu tokoh Muslim yang pemikirannya sangat luas dan mendalam dalam berbagai hal diantaranya dalam masalah pendidikan. Pada hakikatnya usaha pendidikan menurut Al-Ghazali adalah dengan mengutamakan beberapa hal terkait yang diwujudkan secara utuh dan terpadu karena konsep pendidikan yang dikembangkannya berawal dari kandungan ajaran dan tradisi Islam yang menjunjung berprinsip pendidikan manusia seutuhnya.

Dengan memahami dan menjalankan nilai-nilai pendidikan dalam perspektif Imam al-Ghazali, diharapkan pendidikan yang selama ini berjalan menjadi lebih bermakna, tidak hanya berorientasi pada hal-hal yang sifatnya materi saja, tetapi juga harus berorientasi pada kehidupan akhirat kelak. Berpijak pada pemahaman di atas, diharapakan ilmu apapun yang dipelajari selama tidak bertentangan dengan ajaran Islam dapat menjadikan pemilknya mejadi lebih baik, dan tentunya diharapkan bisa merubah wajah bangsa Indonesia menjadi negara yang maju, bebas dari korupsi, tidak ada perselisihan, karena para warganya percaya, bahwa apa yang dilakukan di dunia akan dimintai pertanggungjawaban di akhirat kelak.

Dari uraian diatas adapun rumusan masalah dalam kajian ini adalah (1) Bagaimana pemikiran al-Ghazali tentang ilmu pengetahuan; dan (2) bagaimana pemikiran al-Ghazali tentang konsep pendidikan menurut Islam.

Secara umum penelitian ini bertujuan untuk mengetahui konsep pendidikan agama islam menurut Imam Al-Ghazali, Adapun tujuan spesifik penelitian ini adalah (1) Untuk mengetahui pemikiran al-Ghazali tentang ilmu pengetahuan, dan (2) Untuk mengetahui pemikiran al-Ghazali tentang konsep pendidikan menurut Islam.

\section{KONSEP TEORI \\ Konsep Tentang Ilmu Pengetahuan}

Ilmu dalam terminologi bahasa Arab berarti pengetahuan yang mendalam, pengetahuan tentang hakikat sesuatu. Pengetahuan tersebut bisa melalui proses pencarian, belajar, meneliti, maupun tanpa melalui proses pencarian akan tetapi langsung diberi (lewat wahyu atau ilham) dari yang Maha Mengetahui. Sesuatu di sini adalah baik masalah-masalah empirisindrawiyah maupun masalah-masalah non empiris-supra indrawiyah (Rosyadi, 2004: 68).

Ilmu juga dapat diartikan sebagai yang apabila jika dimilki seseorang maka menjadi jelas apa yang diketahuinya (As'ad, 2007: 14). Sementara itu, ilmu dipandang dari sudut kebahasaan bermakna penjelasan, dipandang dari akar katanya mempunyai arti kejelasan. Semua ilmu yang disandarkan pada manusia mengandung arti kejelasan (Ali, 2002: 383). 
Menurut al-Qur'an ilmu adalah suatu keistimewaan pada manusia yang menyebabkan manusia unggul terhadap makluk-makluk lain. Ini tercermin pada kisah Adam waktu ditanya oleh Allah tentang nama-nama benda. Adam dapat menjawab semua nama benda yang ditanyakan kepadanya. Dalam surah alBaqoroh ayat 38 Allah berfirman sambil memerintahkan, "Hai Adam, beritahukanlah kepada mereka (malaikat dan iblis) nama-nama benda". Adam pun memberitahukan (dengan menyebut nama-nama benda) kepada malaikat dan iblis di hadapan Allah. Berdasarkan keterangan itu al-Qur'an menegaskan, bahwa manusia sejak diciptakan mempunyai potensi berilmu dan mengembangkan ilmunya dengan izin Allah (Ali, 1995: 383-384).

Sedangkan sains dapat diartikan semua pengetahuan yang diperoleh melalui himpunan rasionalitas insani yang dihasilkan dari logika dan kenyataan gejala-gejala alam, suatu eksplorasi ke alam materi berdasarkan observasi dan mencari hubunganhubungan alamiah yang teratur mengenai fenomena yang diamati serta bersifat mampu menguji diri sendiri, dan juga dapat diartikan sebagai usaha manusia dengan menggunakan potensi manusiawinya untuk mengenal sunatullah dari komponen dunia empiris dari sistem ciptaan Allah. Secara sederhana, ilmu memang mengandung arti pengetahuan atau dapat dikatakan tiap-tiap ilmu adalah pengetahuan yang teratur tentang pekerjaan hukum kausal dalam satu golongan masalah yang sama tabiatnya, menurut kedudukannya yang tampak dari luar, maupun menurut bangunannya dari dalam (Rosyadi, 2001: 68-69).

Ilmu pengetahuan merupakan langkah terakhir dalam perkembangan mental manusia dan boleh dianggap sebagai pencapaian tertinggi dan paling karakteristik dalam kebudayaan manusia. Ilmu adalah produk yang lahir kemudian, dan amat canggih yang hanya bisa berkembang berkat kondisikondisi istimewa. Karena pada dasarnya ilmu ialah pengetahuan tentang kebenaran. Sedangkan kebenaran pada hakikatnya adalah sesuatu yang agung, baik dalam penampilannya yang paling sederhana maupun dalam bentuknya yang paling kompleks ataupun yang paling abstrak (Rosyadi, 2001: 68-69).

Pengertian ilmu sebgai pengetahuan itu sesuai dengan asalusul istilah Inggris science yang mempunyai arti mengetahui. Pengetahuan sesungguhnya hanyalah hasil atau produk dari suatu kegiatan manusia. Pengetahuan dikumpulkan manusia melalui penggunaan akalnya kemudian disusun menjadi suatu bentuk yang berpola. Setelah berbagai butir pengetahuan itu dikumpulkan dalam suatu bentuk yang teratur, kumpulan itu disebut ilmu naqliah atau ilmu falsafah, yaitu ilmu yang diperoleh melalui penggunaan akal dan kecendekiaan. Ilmu ini pulalah yang dinamakan sains dan disebut juga ilmu pengetahuan.

Tugas ilmu adalah menjelaskan segala sesuatu yang ada di alam semesta ini agar dapat dipahami, bermanfaat, dan terpelihara. Bagi ilmuan muslim, semuanya itu dalam rangka meningkatkan kualitas iman dan takwa kepada Allah, serta mengagungkan asma-Nya (Muhaimin, 2006: 2)

\section{Pendapat Para Tokoh Tentang Keutamaan Ilmu}

Ali bin Abi Thalib pernah mewasiatkan kepada Kumail, "Wahai Kumail, ilmu adalah lebih utama dari 
pada harta. Ilmu menjagamu, sedang engkaulah yang harus menjaga harta. Ilmu adalah hakim (yang menghakimi), sedangkan harta adalah mahkum (yang dihakimi). Harta akan kurang apabila dibelanjakan, sedangkan ilmu justru bertambah subur apabila dibelanjakan (yakni diajarkan kepada orang lain)" (terj. Al-Baqir, 1996: 20).

Selanjutnya, Fat-al-Mushily pernah berkata, "Bukanlah seorang penderita sakit akan mati apabila tidak diberi makan dan minum?" Orang di sekitarnya menjawab, "Ya." Lalu ia melanjutkan, begitulah hati manusia, apabila dia dihalangi dari hikmah dan ilmu selama tiga hari berturut-turut, maka ia akan mati" (terj. Al-Baqir, 1996: 22). Memang benar apa yang dikatakannya, sebab makanan bagi hati adalah adalah ilmu dan hikmah. Dengan kedua-duanyalah tergantung hidupnya, semua hal itu seperti makanan dan minuman bagi tubuh. Dan barang siapa tidak menyandang ilmu, maka hatinya akan sakit dan kematian pun pasti akan menjelang segera (terj. Al-Baqir, 1996: 23).

Umar bin Khattab pernah berkata,"Wahai manusia, hiasilah dirimu dengan ilmu, sebab Allah memiliki baju yang Ia cintai. Maka barang siapa mempelajari suatu bab ilmu, maka Allah akan mengenakan padanya baju-Nya itu. Dan apabila sesudah itu ia melakukan perbuatan dosa, ia akan mendesaknya tiga kali agar bertobat dari dosanya itu. Agar ia tidak terpaksa mengambil baju-Nya itu, sekiranya orang itu tetap dalam dosanya sampai ia direnggut oleh kematian (terj. Al-Baqir, 1996: 23).

\section{Konsep Pendidikan}

Dalam arti sederhana pendidikan sering diartikan sebagai usaha manusia untuk membina kepribadiannya sesuai dengan nilai- nilai dalam masyarakat dan kebudayaan. Dalam perkembangannya, istilah pendidikan atau paedagogie berarti bimbingan atau pertolongan yang diberikan dengan sengaja oleh orang dewasa agar ia menjadi dewasa. Selanjutnya, pendidikan diartikan sebagai usaha yang dijalankan oleh seseorang atau kelompok orang lain agar menjadi dewasa mencapai tingkat hidup atau penghidupan yang lebih tinggi dalam arti mental (Hasbullah, 1997: 1).

Pendidikan juga dapat diartikan sebagai salah satu usaha untuk membina dan mengembangkan seluruh aspek kepribadian manusia jasmani dan rohani agar menjadi manusia yang berkepribadian, harus berlangsung secara bertahap. Dengan kata lain, terbentuknya kepribadian yang bulat dan utuh sebagai manusia individu, sosial dan sebagai manusia bertuhan hanya dapat tercapai apabila berlangsung proses menuju ke arah akhir pertumbuhan dan perkembangannya sampai kepada titik optimal kemampuannya. Oleh karena itu, berdasarkan pemikiran tadi banyak pakar pendidikan memberikan arti pendidikan sebagai suatu proses dan berlangsung seumur hidup. (Amrullah, dan Djumransjah, 2007: 13). Gambaran di atas dapat diartikan pendidikan dalam arti luas, sedangkan pendidikan dalam arti sempit dapat diartikan pendidikan di sekolah, jadi pendidikan adalah pendidikan formal (Patoni, 2004: 12).

Menurut Dryakarya, pendidikan ialah pemanusiaan manusia muda atau pengangkatan manusia muda ke taraf insani (Hasbullah, 1997: 1). Mengutip pendapat Darmaningtyas, Ngainun Naim dan Ahmad Sauqi dalam bukunya Pendidikan Multikultural Konsep dan Aplikasi, mendefinisikan pendidikan sebagai usaha sadar dan sistematis 
untuk mencapai taraf hidup atau kemajuan yang lebih baik. Titik tekan dari definisi ini terletak pada usaha sadar dan sistematis. Dengan demikian, tidak semua usaha memberikan bekal pengetahuan kepada anak didik dapat disebut pendidikan jika tidak memenuhi kriteria yang dilakukan secara sadar dan sistematis (Naim dan Sauqi, 2008: 30 dan dalam Darmaningtyas, 1999: 3).

Perspektif yang berbeda diberikan oleh tokoh pendidikan pembebasan asal Brasil, Paulo Freire. Menurut Freire pendidikan merupakan jalan menuju pembebasan yang permanen dan terdiri dari dua tahap. Pertama, adalah masa di mana manusia menjadi sadar akan pembebasan mereka, dan melalui praksis mengubah keadaan itu. Kedua, tahap ini dibangun atas tahap yang pertama dan merupakan sebuah proses tindakan kultural yang membebaskan (Collin, 1999: 39).

Dalam Undang-Undang Republik Indonesia tentang Sistem Pendidikan Nasional nomor 20 tahun 2003 pada ketentuan umum pasal 1 menyatakan, pendidikan adalah usaha sadar dan terencana untuk mewujudkan suasana belajar dan proses pembelajaran agar peserta didik secara aktif mengembangkan potensi dirinya untuk memiliki kekuatan spiritual keagamaan, pengendalian diri, kepribadian, kecerdasan, akhlak mulia, serta ketrampilan yang diperlukan diriya, masyarakat, bangsa dan negara (Undang-Undang Republik Indonesia Nomor 20 Tahun 2003 Tentang Sistem Pendidikan Nasional, 2004: 7).

Dalam pandangan Islam arti pendidikan dapat dilihat pada istilah tarbiyah, ta'lim dan ta'dib yang masingmasing memiliki karakteristik makna disamping mempunyai kesesuaian dalam pengertian pendidikan (Shofan, 2004: 38).

Munardji dalam bukunya Ilmu Pendidikan Islam, mengutip istilah tarbiyah dalam Kamus al-Munjid, tarbiyah berasal dari kata rabba, yurabbi, tarbiyatan yang berati tumbuh dan berkembang (Munardji, 2004: 2). Pendapat lain mengatakan tarbiyah berakar dari tiga kata, pertama dari kata rabba-yarbu yang berarti bertambah dan tumbuh, kedua kata rabiya-yarba yang berarti tumbuh dan berkembang, dan ketiga kata rabbayarubbu yang berarti memperbaiki, menguasai, dan memimpin, menjaga, dan memelihara. Kata al-Rabb juga berasal dari kata tarbiyah dan berarti mengantarkan sesuatu pada kesempurnaan secara bertahap atau membuat sesuatu mencapai kesempurnaan secara bertahap atau membuat sesuatu secara sempurna secara berangsur-angsur (Shofan, 2004: 38).

Penggunaan kata tarbiyah terdapat dalam al-Qur'an pada dasarnya mengacu pada gagasan pemilikan seperti pemilikan keturunan orang tua terhadap anak-anaknya untuk melaksanakan kewajiban tarbiyah, yang sifatnya hanya menunjukkan jenis rasional saja. Sedangkan pemilikan yang sebenarnya hanya pada Allah (Amrullah, dan Djumransjah, 2007: 3).

Ayat-ayat al-Qur'an yang berhubungan dengan tarbiyah seperti:

$$
\text { وَقُل رَّبِّ أرَحَمَهُمَا كَمَا رَبَّيَانِى صَغِيرًا }
$$

Artinya: "Wahai Tuhanku, kasihilah mereka keduanya, sebagaimana mereka berdua telah mendidik aku waktu kecil". (QS. al-Isro':24). 


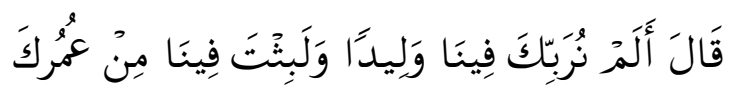

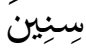

Artinya: "Fir'aun menjawab: "Bukankah Kami telah mengasuhmu di antara (keluarga) Kami, waktu kamu masih kanak-kanak dan kamu tinggal bersama Kami beberapa tahun dari umurmu". (QS. al-Syua'ro:18) (Departemen Agama Republik Indonesia, 1998: 428).

Pengertian pendidikan Islam sebetulnya sudah cukup banyak dikemukakan oleh para ahli. Meskipun demikian, perlu dicermati dalam rangka melihat relevansi rumusan baik dalam hubungan dengan dasar makna maupun dalam kerangka tujuan, fungsi dan proses pendidikan Islam yang dikembangkan dalam rangka menjawab permasalahan dan tantangan yang dihadapi dalam kehidupan umat manusia sekarang dan akan datang, pengertian pendidikan Islam menurut para ahli dapat dijelaskan dalam beberapa keterangan berikut, Ahmad D Marimmba mengartikan pendidikan Islam merupakan bimbingan jasmani dan rohani berdasarkan hukum-hukum agama Islam menuju pada terbentuknya kepribadian utama menurut ukuran Islam. Dari definisi ini jelas pendidikan Islam diartikan bimbingan jasmani dan rohani menurut hukum agama Islam menuju terbentuknya kepribadian yang utama menurut Islam, yang berarti menitik beratkan pada bimbingan jasmani dan rohani berdasarkan ajaran Islam dalam membentuk akhlak yang mulia (Shofan, 2004: 49).

Selanjutnya Soekarno dan
Ahmad Supardi
pengertian pendidikan Islam sebagai
pendidikan yang berasaskan ajaran
atau tuntunan agama Islam dalam
usaha membina dan membentuk
pribadi-pribadi muslim yang bertakwa

kepada Allah, cinta dan kasih kepada kedua orang tua dan sesama hidupnya, cinta kepada tanah air sebagai karunia yang telah diberikan Allah, memiliki kemampuan dan kesanggupan memfungsikan potensi-potensi yang ada dalam dirinya dan alam sekitarnya, hingga bermanfaat dan memberi kemaslahatan bagi diri dan masyarakat pada umumnya (Shofan, 2004: 50-51).

Pendidikan Islam juga dapat diartikan sebagai usaha pembinaan dan pengembangan potensi manusia secara optimal sesuai dengan statusnya, dengan berpedoman kepada syari'at Islam yang disampaikan oleh Rasulullah agar manusia dapat berperan sebagai pengabdi Allah yang setia dengan segala aktivitasnya guna tercipta suatu kondisi kehidupan Islami yang ideal, selamat, aman, sejahtera, dan berkualitas serta memperoleh jaminan (kesejahteraan) hidup di dunia dan jaminan bagi kehidupan yang baik di akhirat kelak (Jalaluddin, 2001: 74).

Djumransjah dan Abdul Malik

Karim Amrullah mengutip pendapat Oemar Muhammad Toumy al-Syaibany mengartikan pendidikan Islam sebagai usaha mengubah tingkah laku individu dalam kehidupan pribadinya atau kehidupan masyarakatnya dan kehidupan dalam alam sekitarnya melalui proses pendidikan. Perubahan yang dimaksud di sini adalah yang berlandaskan nilai-nilai Islam atau berderajat tertinggi menurut ukuran Allah. Perubahan tersebut terjadi dalam proses pendidikan sebagai upaya membimbing dan mengarahkan kemampuan-kemampuan dasar dan belajar manusia (potensi hidup manusia), baik sebagai makhluk individu dan makhluk sosial serta dalam hubungannya dengan alam sekitar (Amrullah, dan Djumransjah, 2007: 19). 


\section{Tinjauan Studi Terdahulu}

Peneltian terdahulu yang membahas tentang pemikiran alGhazali antara lain:

Shafique Ali Khan (2005), menulis tentang Filsafat Pendidikan Al-Ghazali "Gagasan Konsep Teori Dan Fisafat AlGhazali Mengenai Pendidikan, Pengetahuan, Dan Belajar, kajian tersebut membahas pemikiran alGhazali tentang pendidikan yang lebih ditekankan pada pandangan beliau dalam bidang filsafat.

Sibawaihi (2004), mengkaji penelitian tentang pemikiran al-Ghazali yang berkaitan tentang epistemologi ilmu pengetahuan dan kemudian dikomparasi-kan dengan pemikiran kontemporer dari Fazlur Rahman.

Syaefuddin (2005), peneletian menekankan pemikiran al-Ghazali tentang pendidikan Islam dengan merujuk pada keterangan al-Qur'an dan as-Sunnah yang berkaitan dengan pendidikan.

Muhammad Jawad Ridla (2002), menjelaskan teori pendidikan yang meliputi, teori konservatif, religius rasional dan pragmatis intrumental. Adapun al-Ghazali mewakili teori religius rasional, dalam peneltian tersebut lebih dititikberatkan pada pandangan al-Ghazali tentang apa yang harus dilakukan antara guru dan murid dalam proses belajar mengajar.

Margaereth Smith (2000), menjelaskan tentang bagaiamana perjalanan kehidupan al-Ghazali dalam memperoleh ilmu pengetahuan. Adapun titik tekan dalam pembahsannya yaitu tentang pemikiran al-Ghazali yang berkaitan dengan kehidupan yang digali dari ajaran sufi.

Abuddin Nata (2001), menjelaskan tentang bagaimana hubungan antara guru dan murid yang dilihat dari sudut pandang ilmu tasawuf dari sudut pandang al-Ghazali.

\section{METODE PENELITIAN}

Kajian penelitian adalah kajian pustaka, yaitu penampilan argumentasi penalaran keilmuan. Kajian pustaka yang yang di dalamnya memuat beberapa gagasan dan proporsi yang berkaitan dengan kajian didukung oleh data dan informasi yang diperoleh dari sumber pustaka.

\section{Jenis dan Sumber Data}

Sumber data dalam kajian ini dapat dibedakan menjadi dua kategori, yakni, (1) Data primer adalah sumber bahan atau dokumen yang dikemukakan/ digambarkan sendiri oleh orang atau pihak yang hadir pada waktu kejadian yang digambarkan tersebut berlangsung, sehingga mereka dapat dijadikan saksi (Arikunto, 2000: 64). Data primer pada kajian ini adalah Ihya' Ulumuddin, dan Ayyuh al-Walad; dan (2) Data sekunder meruakan bahan pustaka dan dipublikasikan oleh penulisan yang tidak secara langsung melakukan pengamatan atau berpartisipasi dalam kenyataan yang didiskripsikan atau bukan penemu teori (Hajar, 1999: 84). Dalam kajian ini, data sekunder dapat dicontohkan seperti: Pemikiran dan Doktrin Mistis Imam alGhazali, karya Margareth Smith, Reorientasi Pendidikan Islam "Mengupas Relevansi Konsep Pendidikan al-Ghazali Dalam Konteks Kekinian" karya Asrorun Niam Sholeh. Buku dengan judul Nukilan Islam Klasik "Gagasan Pendidikan al-Ghazali" karya Hasan Asari.

\section{Metode Pengumpulan Data}

Metode pengumpulan data atau informasi yang digunakan adalah 
metode dokumentasi. Dokumentasi adalah sesuatu yang tertulis atau tercetak, yang dapat dipakai sebagai bukti atau keterangan (Poerwadarminto, 1984: 256 ). Sedangkan menurut Riyanto (2001:24) metode dokumentasi adalah cara menyimpulkan data dengan mencatat data yang sudah ada.

\section{Teknik Analisa Data}

Teknik analisa data atau informasi merupakan sesuatu yang penting demi terwujudnya validitas penelitian, karena analisa ilmiah terhadap data yang terkumpul memberikan arti tertentu. Untuk menganalisa data dalam penelitian pustaka ini, penulis menggunakan teknik analisa data kualitatif yaitu analisa data reflektif thinking. Maksudnya teknik analisa data dengan proses pemikiran hilir mudik. Pertama, dengan proses induktif yaitu cara berpikir yang berangkat dari fakta-fakta khusus suatu peristiwa yang konkrit kemudian ditarik kesimpulan umum. Kedua, diteruskan dengan proses deduktif yaitu berangkat dan bertitik tolak dari pengetahuan umum untuk menilai kejadian bersifat khusus (Sudjana, 1997: 7).

Selain itu, untuk menganalisa data yang ada, penulis juga menggunakan metode komparatif, yaitu meneliti faktor-faktor dengan situasi atau fenomena yang diselidiki dan membandingkan dari satu faktor dengan faktor lain (Arikunto, 1996: 145).

\author{
HASIL DAN PEMBAHASAN \\ Pemikiran Al-Ghazali Tentang Ilmu \\ Pengetahuan
}

Menurut Al-Ghazali untuk memperoleh derajat atau kedudukan yang paling terhormat di antara sekian banyak makluk di permukaan bumi dan langit karena pengajaran dan pendidikan, karena ilmu dan amalnya. Sesuai dengan pandangan al-Ghazali terhadap manusia dan amaliahnya, bahwa amaliah itu tidak akan muncul dan kemunculannya hanya akan bermakna kecuali setelah ada pengetahuan

Menurut Al-Ghazali, bahwa ilmu pengetahuan itu dasar dari segala kebahagiaan di dunia sekarang maupun di dunia yang akan datang (akhirat). Sementara itu kebahagiaan adalah capain tertinggi yang mungkin diperoleh oleh manusia, maka pengetahuan pun, sebagai dasarnya sesuatu yang sangat tinggi nilainya. Ilmu pengetahuan merupakan fadhilah tanpa mempertimbangkan objek yang diketahui, sehingga pengetahuan mengenai sihir tetap merupakan fadhilah, meskipun tak berguna. Di samping merupakan fadhilah secara intrinsik, ilmu pengetahuan juga sangat penting, karena ia memungkinkan seseorang untuk mencapai hal yang paling berharga, yaitu kebahagiaan abadi. Tak seorang pun akan mencapai kebahagiaan ini tanpa mematuhi perintah-perintah Tuhan, atau tanpa melakukan amal shaleh. Sebaliknya tak seorang pun tahu baik dan buruknya sesuatu tanpa pengetahuan, sehingga mematuhi Tuhan dan melakukan amal shaleh mensyaratkan ilmu pengetahuan. Ini berarti kebahagiaan abadi hanya mungkin dicapai dengan mempunyai pengetahuan.

Adapun ilmu pengetahuan dapat diartikan sebagai langkah terakhir dalam perkembangan mental manusia dan boleh dianggap sebagai pencapaian tertinggi dan paling karakteristik dalam kebudayaan manusia. Ilmu adalah 
produk yang lahir kemudian, dan amat canggih yang hanya bisa berkembang berkat kondisi-kondisi istimewa. Karena pada dasarnya ilmu ialah pengetahuan tentang kebenaran. Sedangkan kebenaran pada hakikatnya adalah sesuatu yang agung, baik dalam penampilannya yang paling sederhana maupun dalam bentuknya yang paling kompleks ataupun yang paling abstrak.

Al-Ghazali membagi ilmu-ilmu berdasarkan kewajibannya terdiri dari:

a) hukum mempelajarinya fardhu 'ayn,b) hukum mempelajarinya fardhu kifayah. Dalam situasi tertentu, ilmu pengetahuan yang fardhu kifayah bisa saja berada menjadi fardhu 'ayn, yaitu manakala satu masyarakat tidak mempunyai sejumlah ahli yang memadai pada bidang ilmu pengetahuan yang sangat dibutuhkan untuk kesejahteraan anggotanya.

Ilmu fardhu 'ayn adalah ilmu yang dibutuhkan untuk melaksanakan tugastugas akhirat dengan baik. Dimana ilmu fardhu 'ayn adalah ilmu yang wajib dipelajari oleh setiap individu seperti ilmu agama dan cabang-cabangnya yang bersumber pada kitab Allah.

Al-Ghazali mengungkapkan bahwa bidang ilmu pengetahuan yang termasuk fardhu kifayah seperi: ilmu kedokteran, ilmu hitung, pertanian, pertenunan, perindustrian, ketrampilan jahit-menjahit, politik dan sebagainya. Namun, prioritas-prioritas ilmu pengetahuan yang fardhu kifayah dalam prakteknya masih diacuhkan, sehingga menimbulkan situasi yang tidak seimbang antara dokter-dokter Islam dan para ulama fiqh, karena ulama fiqh banyak dijumpai pada masyarakat dalam jumlah yang berlebihan sehingga melibihi kebutuhan masyarakat. Bahkan mereka belajar ilmu fiqh adalah sekedar mengumpulkan harta benda pribadi dan untuk diangkat menjadi pejabat pemerintah di bidang hukum dan administrasi. Padahal menurut alGhazali bahwa kemanfaatan dan kebutuhan mayarakat dalam sebuah konteks ruang dan waktu yang dinamis harus menjadi kriteria untuk perkembangan tenaga ahli sesuai dengan bidang ilmu pengetahuan yang fardhu kifayah tersebut, bukan untuk kepentingan dan keuntungan individu.

$$
\text { Sementara itu Al-Ghazali }
$$
membedakan Ilmu pengetahuan berdasarkan sumbernya dibedakan menjadi dua, yakni, (1) Ilmu Syari'ah yaitu segala pengetahuan yang secara langsung membahas hal-hal keagamaan dan pada umumnya diperoleh dari dan dikembangkan berdasarkan al-Qur'an dan as-Sunnah; dan (2) Ilmu ghoiru syari'ah/ilmu aqliah adalah ilmu-ilmu yang bersumber dari akal, baik yang diperoleh secara dlaruri atau iktisabi. Dlaruri adalah ilmu yang diperoleh dari insthing akal itu sendiri tanpa melalui taqlid atau indera, dari mana dan bagaimana datangnya, manusia tidak mengetahuinya. Misalnya pengetahuan manusia, seseorang tidak ada pada dua tempat dalam waktu yang sama. Pengetahuan dlaruri ini juga dapat dikatakan bersifat langsung, serta merta, intuitif, supra rasional dan kontemplatif. Sedangkan yang iktisabi dapat diartikan sebagai ilmu yang diperoleh melalui kegiatan belajar dan berpikir. Ilmu ini ada yang bersifat duniawi seperti ilmu politik, kedokteran, matematika dan lain-lain. Sedangkan yang bersifat ukhrawi seperti, ilmu tentang ihwal hati, bahayabahaya amal, ilmu tentang Allah termasuk sifat-sifat-Nya.

\section{Pemikiran Al-Ghazali Tentang Konsep Pendidikan Islam}

Konsep pendidikan Islam adalah upaya transformasi nila-nilai yang 
sesuai dengan ajaran Islam dengan meletakkan al-Qur'an dan Sunnah Nabi Muhammad saw sebagai acuan utama. Secara umum sistem pendidikan Islam mempunyai karakter religius serta kerangka etik dalam tujuan dan sasarannya. Pemikiran pendidikan alGhazali secara umum bersifat religiusetis. Kecenderungannya ini dipengaruhi oleh penguasaannya di bidang sufisme. Menurut Al-Ghazali pendidikan yang benar merupakan sarana untuk mendekatkan diri kepada Allah. Pendidikan juga dapat mengantarkan manusia untuk menggapai kebahagiaan di dunia dan akhirat. Pendidikan juga sarana menebar keutamaan. Maka untuk mencapai hal itu, dunia pendidikan harus memperhatikan beberapa faktor yang cukup urgens. AlGhazali berpandangan bahwa dunia pendidikan harus menempatkan ilmu pengetahuan pada posisi yang sangat terhormat, penghormatan atas ilmu merupakan suatu keniscayaan. Konsekuensi atas penghormatan terhadap ilmu adalah penghormatan terhadap guru. Ilmu pengetahuan menurut Imam al-Ghazali adalah sebagai kawan di waktu sendirian, sahabat di waktu sunyi, penunjuk jalan pada agama, pendorong ketabahan di saat kekurangan dan kesukaran.

Disamping itu, terdapat hal yang sangat penting dalam mengkaji pemikiran Imam al-Ghazali dalam pendidikan, yaitu pandangannya tentang hidup dan nilai-nilai kehidupan yang sejalan dengan filsafat hidupnya, meletakkan dasar kurikulum sesuai dengan porsinya, serta minatnya yang besar terhadap ilmu pengetahuan. Nasihat terbaik yang dipesankan oleh Imam al-Ghazali dalam pendidikan anak-anak ialah memperhatikan masalah pendidikannya sejak permulaan umurnya, karena bagaimana adanya seorang anak, begitulah besarnya nanti. Bila kita perhatikan pendidikannya di waktu kecil, ia pasti bersifat baik bila ia besar.

Konsep pendidikan menurut alGhazali, dapat diketahui antara lain dengan cara mengetahui dan memahami pemikirannya yang berkenaan dengan berbagai aspek yang berkaitan dengan pendidikan, yaitu tentang faktor-faktor pendidikan seperti aspek tujuan pendidikan, pendidik, anak didik, alat-alat pendidikan dan lingkungan yang mempengaruhi anak didik.

Adapun faktor-faktor pendidikan Al-Ghazali menyatakan, (a) tujuan utama dalam menuntut ilmu adalah untuk memperoleh kebahagiaan hidup di dunia dan akhirat, maka yang dijadikan landasan utama dalam bidang pendidikan adalah al-Qur'an dan Hadis. Sementara itu, tujuan akhir kegiatan pendidikan ada dua, yaitu pertama, tercapainya kesempurnaan insani yang bermuara pada pendekatan diri kepada Allah, dan kedua kesempurnaan insani yang bermuara pada kebahagiaan dunia dan akhirat. Karena itu, ia bercita-cita mengajarkan manusia agar mereka sampai pada sasaran-sasaran yang merupakan tujuan akhir dan maksud pendidikan itu. Tujuan ini tampak bernuansa religius dan moral, tanpa mengabaikan masalah duniawi; (b) seorang pendidik harus mempunyai niat awal dalam mendidik untuk mendekatkan diri kepada Allah, dapat menjadi tauladan bagi murid-muridnya serta mempunyai kompetensi dalam mengajar ditandai dengan penguasaan materi, sikap yang objektif, dan memperlakukan anak didiknya seperti anaknya sendiri; (c) anak didik dalam belajar juga harus mempunyai niat untuk mendekatkan diri kepada Allah, sebisa mungkin menjauhi maksiat karena ilmu itu suci dan tidak akan deberikan kepada hal yang tidak suci, 
menghormati guru dan tentunya rajin belajar dengan mendalami pelajaran yang telah diberikan gurunya (d) kurikulum (alat pendidikan) sebagai alat pendidikan harus disesuaikan dengan perkembangan anak didik. Anak didik diberikan materi pelajaran secara bertahap dengan memilihkan materi yang mudah kemudian menuju materi yang lebih sulit, dan materi ke-tauhidan hendaknya dijadikan landasan utama sebelum diberikan materi-materi pelajaran yang lain. Bentuk-bentuk kurikulum pendidikan dapat dicontohkan seperti perintah larangan, dorongan, hambatan, nasehat, anjuran, hadiah, hukuman, pemberian kesempatan dan menutup kesempatan; (e) lingkungan pendidikan terdiri tiga bagian, yakni : lingkungan keluarga, lingkungan sekolah dan lingkungan masyarakat. mengenai lingkungan, anak didik harus dijauhkan dari pergaulan yang tidak baik, karena lingkungan yang jelek akan mempengaruhi perkembangan anak didik. Oleh karena itu dari semua lingkungan yang ada di sekitar anak didik hendaknya harus memberikan dorongan ke arah yang lebih baik.

Sementara itu, wujud penerapan dari nilai-nilai pendidikan dalam perspektif al-Ghazali di masa sekarang dapat ditandai dengan muculnya ideide membentuk suatu lembaga formal yang bernuansa Islam seperti, TK plus, Sekolah Islam Terpadu (SD, SMP, SMA), Sekolah Tinggi Islam/Perguruan Tinggi Islam, dan lain-lain. Lembaga-lembaga bernuansa islam tersebut, nilai-nilai pendidikan Islam diterapkan dalam bentuk praktek langsung melalui kegiatan sekolah, seperti sholat dhuha, tadarus al-Qur'an dan sholat fardhu dengan berjama'ah. Penerapan pendidikan Islam yang ada di Indonesia sebenarnya sudah diterapkan jauh-jauh hari dalam lingkungan pondok pesantren dengan diajarkannya berbagai pelajaran tentang Islam dan nilai-nilai kehidupan yang digali dari falsafah Islam yang telah diajarkan oleh Rasulullah. Hal ini membuktikan meski dianggap ketinggalan zaman ternyata nilai-nilai pendidikan Islam yang digambarkan Imam al-Ghazali secara esensi masih bisa diterapkan bahkan menjadi roh bagi dunia pendidikan yang dapat mengontrol moral anak didik. Teori pendidikan yang telah digambarkan al-Ghazali asalkan tidak dianggap yang paling benar, dalam arti perlu dipadukan dengan teori-teori pendidikan modern tentunya akan menciptakan suatu bentuk teori pendidikan yang mampu melahirkan produk-produk pendidikan yang cakap ilmu pengetahuan dengan dihiasi pribadi yang bermoral Islami.

\section{SIMPULAN}

Berdasarkan uraian dari pembahasan di atas dapat diambil kesimpulan sebagai berikut: (1) Ilmu Pengetahuan adalah sumber untuk memperoleh kebahagiaan di dunia dan akhirat. Kebahagiaan itu tidak dapat diperoleh tanpa adanya ilmu pengetahuan mengenai caranya memperoleh kebahagiaan tersebut, maka peran ilmu pengetahuan sangatlah penting bagi kehidupan. Sementara itu, ilmu pengetahuan hanya dapat diperoleh melalui pendidikan. Dengan ilmu pengetahuan akan menjadikan manusia menjadi makhluk yang mulia dan terhormat dibandingkan makhluk lainnya; dan (2) Pemikiran al-Ghazali tentang konsep pendidikan Islam Pertama, faktorfaktor pendidikan pendidikan islam, yakni (a) tujuan utama dalam menuntut ilmu adalah untuk memperoleh kebahagiaan hidup di dunia dan akhirat, maka yang dijadikan landasan 
utama dalam bidang pendidikan adalah al-Qur'an dan Hadist; (b) seorang pendidik harus mempunyai niat awal dalam mendidik untuk mendekatkan diri kepada Allah, menjadi tauladan bagi murid-muridnya serta mempunyai kompetensi dalam mengajar ditandai dengan penguasaan materi, sikap yang objektif, dan memperlakukan anak didiknya seperti anaknya sendiri; (c) anak didik dalam belajar harus mempunyai niat untuk mendekatkan diri kepada Allah, menjauhi maksiat karena ilmu itu suci dan tidak akan deberikan kepada hal yang tidak suci, menghormati guru dan rajin belajar dengan mendalami pelajaran yang telah diberikan gurunya; (d) kurikulum sebagai alat pendidikan harus disesuaikan dengan perkembangan anak didik; (e) anak didik harus dijauhkan dari pergaulan yang tidak baik, karena lingkungan yang jelek akan mempengaruhi perkembangan anak didik, terutama dilingkungan keluarga, sekolah atau masyarakat. Kedua, wujud penerapan nilai-nilai pendidikan dalam perspektif al-Ghazali di masa sekarang ditandai dengan munculnya modelmodel lembaga pendidikan yang mencantumkan nilai-nilai pendidikan Islam dalam kurikulumnya, seperti sholat dhuha, tadarus al-Qur,an dan sholat berjama'ah.

\section{DAFTAR RUJUKAN}

Al-Ghazali, Abu Hamid Muhammad bin Muhammad. Ihya' Ulumuddin I. Beirut: Darul Fikr, lihat juga Abu Hamid Muhammad bin Muhammad al-Ghazali. Ihya' Ulumuddin I. Ilmu dalam Perspektif Tasawuf al-Ghazali. terj. Muhammad, Al-Baqir. 1996. Bandung: Karisma.
Ali, Mohammad Daud. 1995. LembagaLembaga Islam di Indonesia. Jakarta, PT. Raja Grafindo Persada. __, Mohammad Daud. 2002. Pendidikan Agama Islam. Jakarta: PT Raja Grafindo Persada

Amrullah, Abdul Malik Karim. dan Djumransjah. 2007. Pendidikan Islam Menggali Tradisi Mengukuhkan Eksistensi. Malang: UIN-Malang Press.

Arikunto, Suharismi. 2000. Manajemen Penelitian. Jakarta: Rineka Cipta. Suharismi. 1996. Prosedur Penelitian. Jakarta: Rineka Cipta.

As'ad, Aliy. 2007. Tarjamah Ta'lim Muta'alim. Bimbingan Bagi Penuntut Ilmu Pengetahuan. Kudus: Menara Kudus. Aliy. 1978. Bimbingan Bagi Penuntut Ilmu. judul asli Ta'lim alMuta'alim Thariq al-Ta'allum Kudus: Menara Kudus.

Collin, Denis. 1999. Paulo Freire Kehidupan Karya dan Pemikirannya. Yogyakarta: Pustaka Pelajar.

Departemen Agama Republik Indonesia. 1998. al-Qur'an dan Terjemahannya. Surabaya: AlHidayah.

Hajar, Ibnu. 1999. Metodologi Penelitian Kuantitatif dalam Pendidikan. Jakarta: Raja Grafindo Persada.

Hasbullah. 1997. Dasar-Dasar Ilmu Pendidikan. Jakarta: PT Raja Grafindo Persada.

Jalaluddin. 2001. Theologi Pendidikan. Jakarta: PT Raja Grafindo Persada.

Muhaimin. 2006. Nuansa Baru Pendidikan Islam Mengurai Benang Kusut Dunia Pandidikan. Jakarta: PT Raja Grafindo Persada.

Munardji. 2004. Ilmu Pendidikan Islam. Jakarta: PT Bina Ilmu. dalam Lois Ma'luf. 1951. Kamus al-Munjid. Bairut: Al Maihbah Al Kathalikyah. 
Nata, Abuddin. 2001. Perspektif Islam Tentang Pola Hubungan GuruMurid "Studi Pemikiran Tasawuf al-Ghazali". Jakarta: PT Raja Grafindo Persada.

Ngainun, naim. 2009. Rekontruksi Pendidikan Nasional. membangun paradigm yang mencerahkan. Yogyakarta: TERAS.

Nurdin, Muhammad. 2008. Kiat Menjadi Guru Profesional. Jakarta: Ar-Ruzz, Media Group.

Patoni, Achmad. Metodologi Pendidikan Agama Islam. Jakarta: PT Bina Ilmu.

Poerwadarminto. 1984. Kamus Umum Bahasa Indonesia. Jakarta: Balai Pustaka.
Rosyadi, Khoiron 2004. Pendidikan Profetik. Yogyakarta: Pustaka Pelajar.

Sauqi, Ahmad dan Ngainun Naim, Pendidikan Multi Kultural Konsep dan Aplikasi, Yogyakarta: Ar-Ruz Media Group, 2008.

Shofan, M. 2004. Pendidikan Berparadigma Profetik Upaya Konstruktif Membongkar Dikotomi Sistem Pendidikan Islam. Yogyakarta: Ircisod.

Sudjana, Nana. 1997. Tuntunan Penyusunan Karya Ilmiah. Bandung: Sinar Baru Algensindo.

Undang-Undang Republik Indonesia Nomor 20 Tahun 2003 Tentang Sistem Pendidikan Nasional. Jakarta: Qonon Publishing, 2004. 